\title{
地上風向の日変動パターンを用いた 夜間の熱中症危険度指標の考察
}

\author{
玉井 昌宏 ${ }^{1 *}$. 澤井 健志 $^{2}$ \\ ${ }^{1}$ 大阪大学大学院工学研究科地球総合工学専攻（干565-0871吹田市山田丘2-1) \\ E-mail:tamai@civil.eng.osaka-u.ac.jp \\ 岐阜県県土整備部砂防課（干500-8570岐阜市薮田南2-1-1） \\ E-mail:sawai-kenji@pref.gifu.lg.jp
}

\begin{abstract}
WBGTは最も一般的に用いられている熱中症の危険度指標であり，運動時や日常生活の指針としても活用 されている，ところが，この指標值の低下する夜間においても熱中症罹患者は発生することが知られてお り，WBGTだけで危険性を予測することは難しい. 何らかの別の指標の開発し，さらに，それに基づく指 針の策定が必要であると考える。本論では，地上風向の日変動パターンがWBGTに代わる指標として利用 可能であるかどうかについて，大阪市消防局の熱中症患者の救急搬送データを用いて検討する。このパタ ーンによってWBGT值の変動傾向に差異が生じることを示したうえで, 暑熱環境の履歴を考慮できる新し い指標を提案する。この指標の月別パターン別の平均值が夜間熱中症罹患率と強い相関関係にあること, 加えて，一日中西風が連吹するパターンWが夜間熱中症に対して最も危険な気象状況であることを示す. これらから，地上風向の日変動パターンが一つの夜間の熱中症危険度指標となり得ることを示す.
\end{abstract}

Key Words : heatstroke, disease risk, atmospheric environments, meteorological scenario, land and sea breeze

\section{1. はじめに}

熱中症は暑熱環境下で発生する健康被害である。その 発症は古くから炭鉱労働や鉄鋼業など種々の産業におい て確認されている。 ${ }^{11}$ 昨今, 室内環境や労働環境が劇的 に改善されているにもかかわらず，この病気が増加傾向 にあるのは, 地球温暖化や都市ヒートアイランド現象な どが背景にあるとされるが2)，空調設備の普及などによ る暑熱環境に対する生理学的な適応能力の低下も影響し ていると考えられる.

最高気温や平均気温など熱中症の危険度を示寸指標は 色々考えられるが3)，WBGT（Wet Bulb Grobe Temperature, 湿球黒球温度) 指標が最も一般的である. WBGTと罹患 者数との間には強い関係性が認められており, 気象庁な どから発せられる注意情報なども，この指標により決め られている. 運動時) の从ならず，日常生活においても 熱中症の注意指針として用いられている.

WBGTの指針では， $25^{\circ} \mathrm{C}$ をつの閾値として，それ未
満では熱中症の危険性は概して小さいとされている. ${ }^{2)}$ しかしながら，夜間等，この基準を下回る時間帯にも罹 患者は発生している. 南5は, 地域固有の気候条件やそ れに対する順応度などによって, 高温に対する許容度が 異なること，環境温度だけでなく高温の継続時間なども 熱中症の危険性に影響することを指摘している. WBGT の時間值を唯一の指標として, $25^{\circ} \mathrm{C}$ 全国一律の閾值と 捉えるのではなく, 地域の気候や生活様式など，様々な 事情に応じた指標の提案や閾值の設定があってよいので はないかと考えられる.

筆者らのは，容易に大気環境リスク評価を行うための 方法として気象シナリオ日を提案するとともに，種々の 問題を引き起こす可能性のある気象シナリオをターゲッ トシナリオとして捉えることを提唱してきた．筆者らの これまでの検討７,8)により，大阪湾沿岸地域において夏季 夜間に高温になりやすい，あるいは熱帯夜日となりやす い地上風向変動パターンがあることが明らかになってい る. こうしたことは, WBGT指標とは異なる情報が, 夜 


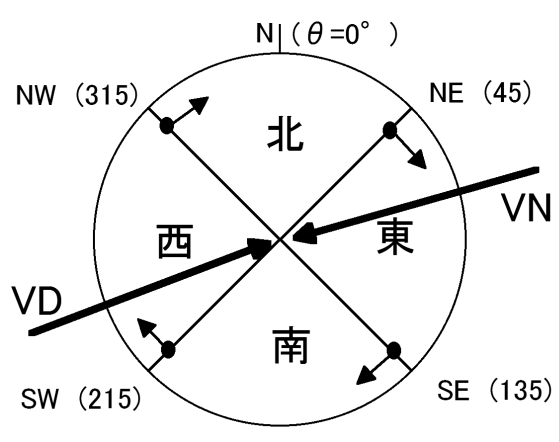

図-1 風向のグループ化

(数字 : 北を 0 度, 右回りの角度, 矢印 : この角度 がどちらのグループに入るかを示している．ここで は，昼間の平均単位ベクトル VDが西に，夜間の単 位ベクトル VNが東に分類されることを例示してい る. )

間熱中症危険度の新しい指標となったり，WBGTなど従 来の指標と組み合わせることで，精度高い注意情報とな る可能性を示していると考えられる.

本論では, まず, 既述の地上風向の日変動パターンが 熱中症危険度の代表指標である WBGT の変動傾向に及 ぼす影響について明らかにする．熱中症危険度指標の変 動履歴を評価する簡易な指標を提案し，それと地上風向 の日変動パターンや夜間の熱中症罹患者数との関連性に ついて検討する.これらのことを通じて, 地上風向日変 動パターンが夜間における熱中症の危険度の一つの指標 となり得ることを示す. 分析対象地域は大阪市域とし, 気象データとしてアメダス大阪のデータを，熱中症デー タとして大阪市消防局の熱中症罹患者の搬送者数データ を用いる. 分析対象年度は 2008-2012 年の 5 年間とする.

\section{2. 方法}

\section{（1）地上風向の日変動パターン}

ここでは，大阪市域を分析対象地域とし，地上風向の 日変動パターンの分類には，アメダス大阪（北緯 : 34 度 40.9 分, 東経 : 135 度 31.1 分, 標高 : $23 \mathrm{~m}$, 設置位 置 : 大阪市中央区）における地上風向データを用いた. 詳細な方法は筆者らの方法旬と同様である. 9 時〜21 時 を昼間， 21 時から翌 9 時までを夜間とし，昼夜の平均 風向の組み合わせで気象パターンの分類を行った. 平均 風向は，各時間の風向の単位ベクトルを昼間あるいは夜 間にわたって単純に加算することにより求めた. この平 均風向を東西南北 4 つの風向に分類した. 例えば, 図-1 は昼の平均風向VDと夜の平均風向VNがそれぞれ西風と 東風に分類されることを示している．表-1 は昼夜の平 均風向の組み合わせとパターンとの関係を示している.
表-1 気象パターン分類

\begin{tabular}{c|c|c|c}
\hline パターン & 昼間 & 夜間 & 気象状況 \\
\hline $\mathrm{A}$ & 西風 & 東風 or 北風 & 海陸風交替 \\
\hline $\mathrm{W}$ & 西風 & 西風 or 南風 & 西風連吹 \\
\hline $\mathrm{N}$ & 北風 & - & 北風連吹 \\
\hline $\mathrm{E}$ & 東風 & - & 東風連吹 \\
\hline $\mathrm{S}$ & 南風 & - & 南風連吹 \\
\hline
\end{tabular}

筆者らのこれまでの検討,77により，いずれの地上風向 変動パターンが発生するかは, 地衡風ベクトルと日積算 全天日射量によって説明できることがわかっている，但 し, 昼夜の平均風向の組み合わせは, このふたつ以外の 要因によって発生することもある. そこで, このように 偶然発生した日を取り除くために，地上風向の日変動パ ターンを目的変数, 9 時と 21 時の地衡風ベクトルと日 積算全天日射量を説明変数として判別分析を行った. こ れらの説明変数で予想されるパターンとアメダスの風向 データにより決定される実際のパターンとが一致しない 誤判別の日を除いて検討を進めることにした．説明変数 の日積算全天日射量は大阪管区気象台の観測データを用 いた，地衡風ベクトルは，輪島，潮岬，米子または松江 地点の高層気象観測データから算出した。 なお, 2009 年までは米子のデータを, 2010 年以降は松江のデータ を用いた。

\section{（2）WBGT と熱中症データ}

次式を用いて, WBGTを算出した. ${ }^{9,10)}$

$$
\mathrm{WBGT}=0.7 \mathrm{Tw}+(0.3-\alpha) \mathrm{Tg}+\alpha \mathrm{Ta}
$$

ここに, $\operatorname{Tw}\left({ }^{\circ} \mathrm{C}\right)$ : 湿球温度, $\operatorname{Tg}\left({ }^{\circ} \mathrm{C}\right)$ : 黒球温度, $\mathrm{Ta}$ $\left({ }^{\circ} \mathrm{C}\right)$ : 乾球温度, $\alpha$ :日射の影響を示すパラメータである. 日射が無い場合は黒球温度と乾球温度が等しくなるため $\alpha=0.0$, 日射がある場合は $\alpha=0.1$ とする. 各パラメー タに関して, 乾球温度については大阪管区気象台の気温 の観測值をそのまま用い，黒球温度は以下の式から算出 した. ${ }^{9,11)}$

$\mathrm{Tg}$

$=\left\{\begin{array}{cc}\mathrm{Ta}+12.1+0.0067 \mathrm{~S}-2.40 \mathrm{U}^{1 / 2} & \left(\mathrm{~S} \geq 400 \mathrm{~W} / \mathrm{m}^{2}\right) \\ \mathrm{Ta}-0.3+0.0256 \mathrm{~S}-0.18 \mathrm{U}^{1 / 2} & \left(\mathrm{~S}<400 \mathrm{~W} / \mathrm{m}^{2}\right)\end{array}\right.$ ここに, $\mathrm{S}\left(\mathrm{W} / \mathrm{m}^{2}\right)$ : 全天日射量, $\mathrm{U}(\mathrm{m} / \mathrm{s})$ : 風速である. 湿 球温度は, 以下の式を用いて算出した。

$$
\mathrm{e}_{\mathrm{s}}-\mathrm{e}=\frac{\mathrm{C}_{\mathrm{p}} \mathrm{p}}{\varepsilon \mathrm{L}}(\mathrm{Ta}-\mathrm{Tw})
$$

ここに, $\mathrm{e}_{\mathrm{S}}(\mathrm{hPa})$ : 飽和水蒸気圧, $\mathrm{e}(\mathrm{hPa})$ : 水蒸気圧, $\mathrm{C}_{\mathrm{P}}(=1004 \mathrm{~J} / \mathrm{kgK})$ : 定圧比熱, $\mathrm{p}(\mathrm{hPa})$ : 大気压, $\varepsilon(=0.622)$ : 定数, $\mathrm{L}(=2.5 \mathrm{E} 6 \mathrm{~J} / \mathrm{kg})$ : 潜熱である. 飽 和水蒸気圧は, 乾球温度と Tetens $の$ 蒸気圧算定式加ら算 出した. なお, 気温, 湿度, 水蒸気圧, 風速, 全天日射 
量のデータには，大阪管区気象台で観測されたものを用 いた．全天日射量データから日射の有無を判定し，その 結果に応じた WBGT值を用いた.

熱中症罹患者数については，大阪市消防局管内の熱中 症による救急搬送者数データを用いた．記載されたデー 夕項目のうち，救急搬送された日時データのみ用いた. 同管内の気象状況は，大阪管区気象台におけるものと同 一であると仮定して，分析を進めた．なお，2008２012 年の 6 9月の 20 か月間で, 救急搬送されて熱中症と診 断された人数は 3183 人にのぼる.

\section{3. 結果と考察}

\section{（1）地上風向の日変動パターンの頻度}

図-2 は，6〜9月の各風向変動パターンの生起日数で あり，2008 より 2012 年の 5 年間の平均值と標準偏差を 示している. パターン $\mathrm{S}$ は, 月によらず発生日数は 3 日 程度である. 説明変数の数による制約条件によって, こ のパターンは, 判別分析から除外されることが多くなっ ている. パターン A については, 月による変動は小さ < 8 10 日程度である. パターン $\mathrm{W}$ の発生日数は，7月 に極大となり，他のパターンより明確に多くなっている。 パターン $\mathrm{N}$ と $\mathrm{E}$ は，7月に極小となっており，W $\mathrm{W}$ 逆位 相になっている. 8月は, A と W ともに 9 日程度で, 次 いで Nが多い. Nは9月に最も多くなっているが，これ は大阪湾の海面水温と地上気温の関係が，昼夜を問わず 陸風が吹きや寸くなる条件になるからである. 図-3 は, 一例として 2010 年一年間の神戸港の海面で計測された 水温, アメダス大阪の日最低気温と日平均気温, 日最高 気温の変動を示している。これらの気温については7日 間の移動平均をとっている。ここでは，神戸港の観測值 を大阪湾の海面水温を代表値と考えている，同図のよう

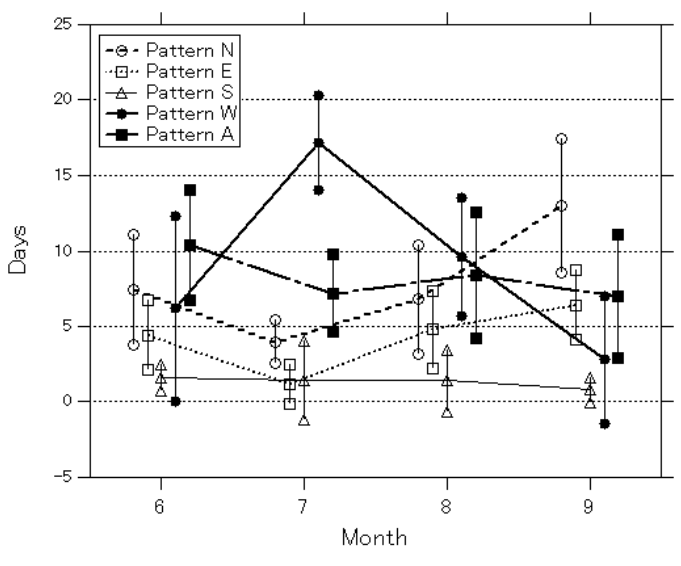

図-2 風向変動パターンの発生日数

に, 大阪湾の水温は 5〜 8 月までは陸域部の平均気温と 最低気温との間にある.9月に入ると，この水温は平均 気温を上回るようになる. 7 月に W が形成されやすい のは海面水温が最低気温付近を変動するからであり，9 月以降に陸風が吹きや寸いのは，海面水温が相対的に高 くなるからであると推測される，なお，地衡風など他の 気象要素との関係については別途検討したい. 図-2の ように，特に熱中症危険度の高まると予想される 7 月や 8 月において, パターン $\mathrm{W}$ や A 発生頻度が高いこと がわかる。

\section{（2）各風向変動パターンと WBGT}

図-4 は, 2010 年 6〜9 月の各風向変動パターンの WBGT の時間変動特性を示している. 月別各パターン の各時間の WBGT の平均值と標準偏差を求めて時系列 で示している.

(a)の 6 月では，いずれのパターンも 6 時ごろまで平均 值は $20^{\circ} \mathrm{C}$ 程度である. 日中の平均值が $25^{\circ} \mathrm{C}$ を超過する

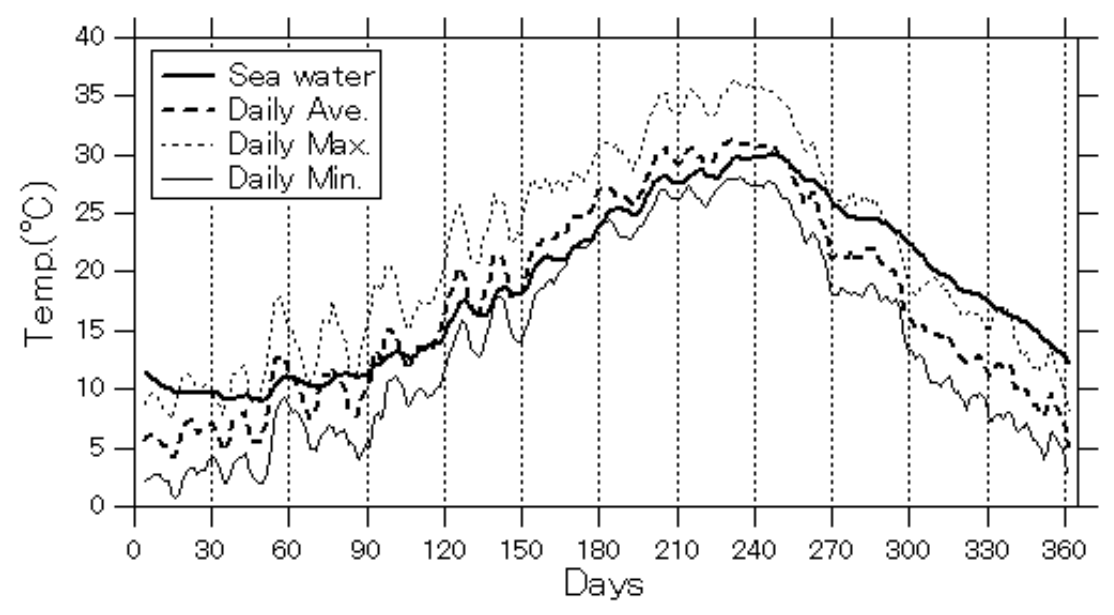

図-3 アメダス大阪の日平均気温，日最高気温，日最低気温と大阪湾の海面水温（2010年） 
のはパターン $\mathrm{W}$ のみであり, 特に昼間の熱中症の危険 度はこのパターンにおいて大きくなると考えられる. 夜 間についても平均値そのものはパターン W が大きくな っているが，パターン間で有意な差はなかった．海陸風 交替の発生するパターン A が最も気温が高くなると考 えがちである，そのようにならないのは，図-3 の気温 の時系列で示したように，この時期の大阪湾の海面水温
が大阪の気温に比較して低いことに関係している．海陸 風交替が発生するためには，夜間にこの水温より陸域の 気温が低くなることが必要になり，日中に日射量の少な い日，あるいは夜間に強い放射冷却が生じる日に，パタ ーン A が発生しやすくなる. (b)の 7 月においては, パ ターン内の標準偏差は小さくなり, 各時間のパターン間 の差異が顕著になる。 S を除くパターンにおいて, 昼間

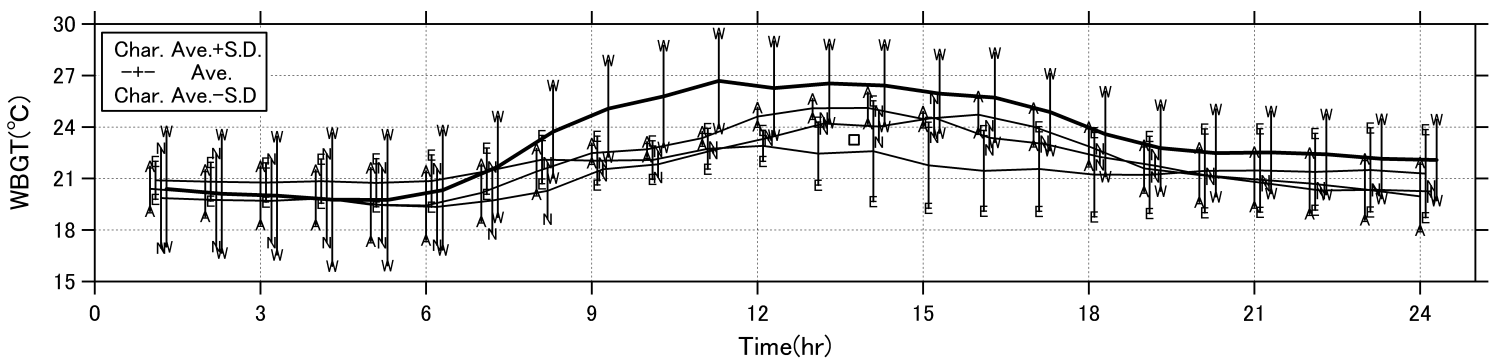

(a)6月

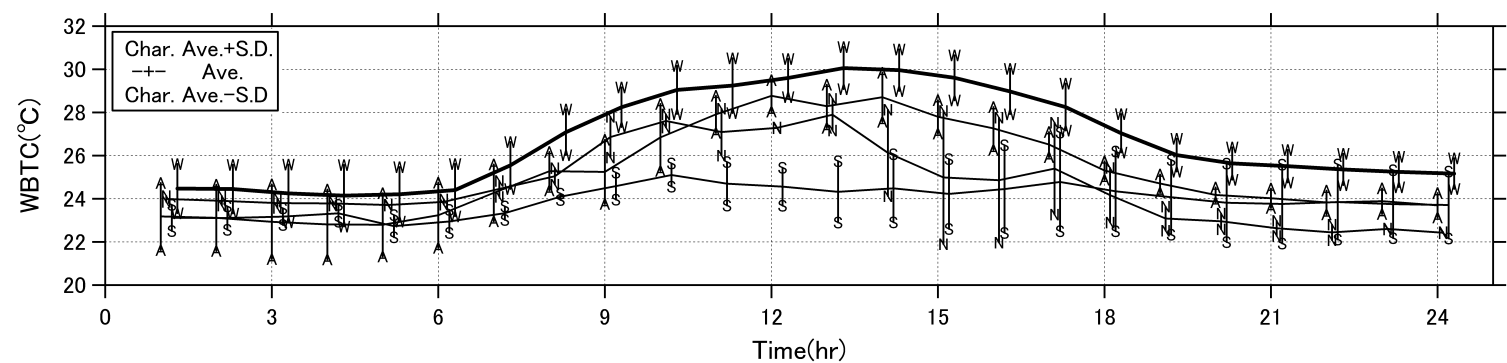

(b)7 月

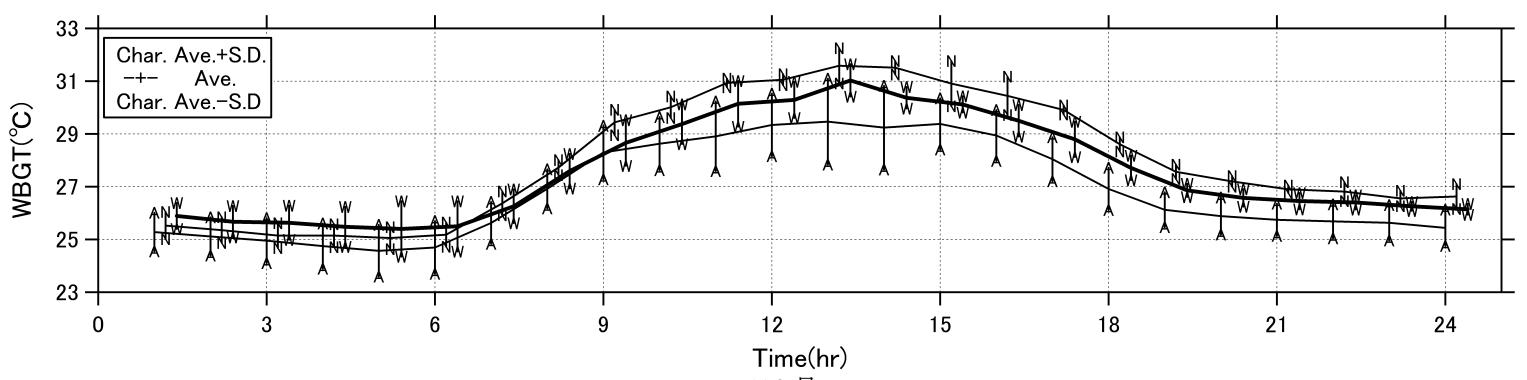

(c)8 月

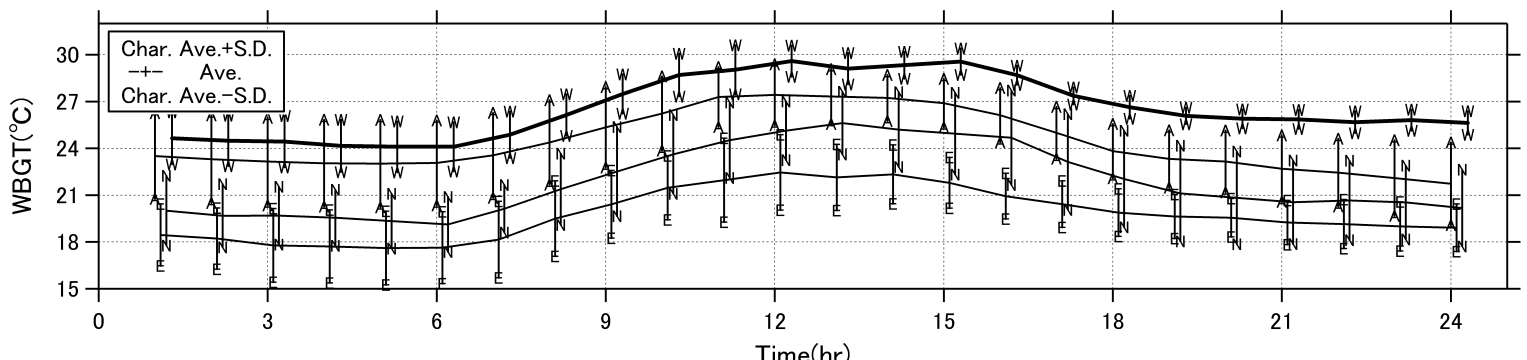

(d)9月

図-4 各風向変動パターン毎の WBGT の時間変動特性 
の平均值は $25^{\circ} \mathrm{C}$ を回るようになり危険度が高くなる. パターン $\mathrm{W}$ は， A $\mathrm{N}$ より大きくなっていることがお かる.この大小関係は，夜間においても継続しており， $\mathrm{W}$ の平均值は夜間にも $25^{\circ} \mathrm{C}$ 越えている.

(c)の 8 月においては，いずれのパターンにおいても平 均值は一日中 $25^{\circ} \mathrm{C}$ を越えている。夜間においてパター ン $\mathrm{N}$ が最も高くなっているが，これはフェーン現象が 発生すると, 大阪平野の地上風は淀川に沿って北東より に吹くことが多いからである. (c)の 8 月のパターン N の日は 4 日間あったが，いずれもフェーン現象による高 温が観測された日である。但し，この現象の発生は年に よってまちまちであり, 必ずしも $\mathrm{N}$ が高温になるわけ でない.8月において，このパターンは移動性の高気圧 や低気圧，台風の通過により発生することが多い. (d) の 9 月のパターン内の変動は大きくなっているが，パタ ーン W の平均值は早朝より深夜まで概ね $25^{\circ} \mathrm{C}$ を超過し ており, 他のパターンと比較して, 熱中症危険度は高い これらの結果より。18hr 以降の夜間において熱中症危険 度が高いのは，7，9月のパターン W，8月の全てのパタ ーンであることがわかる。

\section{（3）履歴を考慮した熱中症危険指数}

既述の通り，WBGT が $25^{\circ} \mathrm{Cを}$ 越える時間が短い場合 より, 長時間継続するほうが熱ストレスは大きくなるだ ろう。ここでは, このストレスの履歴を考慮するために, 以下の指標について検討する.

$$
\mathrm{Y}(\mathrm{T})=\sum_{\mathrm{t}=7}^{\mathrm{T}}[\operatorname{WBGT}(\mathrm{t})-25]
$$

ここに, $\mathrm{Y}(\mathrm{T})(\mathrm{C})$ : 各日の時刻 $\mathrm{T}$ における履歴を考慮し た指標, WBGT(t) : 各日の時刻 $\mathrm{t}$ における WBGT 值で ある.この指標は，WBGT が $25^{\circ} \mathrm{C}$ 以上になると熱中症 の危険度が高くなるとの従来の知見に基づいて，250か らの偏差を単純に加算したものである. 各日の熱ストレ スは起床時にキャンセルされて, それ以降に蓄積される と仮定している. また, 平均的な起床時刻が 6〜 7 時の 間であること, 通常日最低気温は夜明け前ごろ生じるこ となどを勘案して，加算の開始時刻を 7 時としている.

図-5 は 6 9 月の各パターンのY(T)の平均值と標準偏 差の時間変化を示している. ここでは，2008～2012 年の 5 年分のデータを用いて算出している. Y(T)のグラフは, 6 月では全般的に減少傾向にあるものの，その他の月で は昼間に増加，夜間に減少するもの，昼間に上昇し夜間 にそれほど減少しないものなど様々なタイプがある. (a) の 6 月は, いずれのパターンも $\mathrm{Y}(\mathrm{T})$ の平均值は $0^{\circ} \mathrm{C}$ 超 過していない. $\mathrm{W}$ と $\mathrm{S}$ は比較的大きく, 15-18hr 頃の平 均值は概ね $0^{\circ} \mathrm{C}$ とっている, それ以降の時間帯の平均
值の時間勾配にパターン間の大きな差異はなく, 昼間に できた差異が，夜間にまで継続する形となっている．有 意差については後述するが, 各パターンの標準偏差は比 較的大きいものの，6月においては W と S の熱中症危 険度が大きいことが予想される. (b)の 7 月では, パター ン S を除いて, $18 \mathrm{hr}$ ごろまでは増加傾向にある. その後, A と S は減少傾向を示すが，W のみあまり減少せずに 翌朝まで $30^{\circ} \mathrm{C}$ 程度で推移している。 また, 標準偏差に ついては W が最も小さくなり，このパターンの気象状 況が，図-2 で示したように他のパターンより日数が多 いにも関わらず，変動が小さく安定していることがわか る. (c)の 8 月になると, A S における 18hr以降の顕著 な減少傾向は認められなくなり, $\mathrm{Y}(\mathrm{T})=40\left({ }^{\circ} \mathrm{C}\right)$ 程度と なっている. パターン $\mathrm{N}$ は, 図-4(c)の傾向と異なり, 平均值は比較的小さくなっている. これは, 既述の通り 2010 年 8 月のパターン N は全てフェーン現象が関係し ていたが，通常の $\mathrm{N}$ は気圧配置などの影響により北方 からの泠たい空気が流入することにより発生するからで ある. パターン $\mathrm{W}$ の平均值は, 日没後も増加傾向にあ り，60 $\mathrm{C}$ 程度にまで達している. 平均的にみれば, この パターンでは WBGT が一日中 $277^{\circ}$ 上回るような状況 が継続していることになる. (d)の9月の特徴は，パター ン間の差異が大きくなっていることである. 18hr までに 増加傾向を示すのは $\mathrm{W}$ と $\mathrm{A}$ であり，Aについては，そ れ以降減少する. パターン $\mathrm{W}$ については, 18 時以降あ まり減少せず, 概ね $2 \mathrm{Y}(\mathrm{T})=30\left({ }^{\circ} \mathrm{C}\right)$ 程度となっている.

表-2 は, 各月における風向変動パターン間の $\mathrm{Y}(\mathrm{T})$ の 平均值の差の有意性の検証結果である. 18 時以降の時 間帯で，一時間ごとの平均值の差を検定した．表中の矢 印はその方向に示すパターンのほうが大きいことを，（） は 18 時以降全ての時間帯で 1\%有意の差があることを, ○は 5\%有意の差があったことを示す．また，一(横棒) は，当該月において少なくともいずれか一方のパターン が存在しなかったことを示す．7月はパターン E が， 8, 9月はパターンSが発生しなかった.

表-2 から, 全ての月において, パターン W のY(T)は, パターン Aと $\mathrm{N}, \mathrm{E}$ に対して有意に大きい. パターン $\mathrm{S}$ に対しては，6月では有意差はないが，7月では 5\%有 意で大きい. 総じて, パターン W $\mathrm{W}$ - $\mathrm{Y}(\mathrm{T})$ は他のパター ンより有意に大きいと言える. 海陸風交替のパターン $\mathrm{A}$ は総じてNやEに対しては大きい.

図-6 は, 各月, 各パターンのY(T)の平均值の 18 時以 降明け方までの時間帯の平均值 $\bar{Y}\left({ }^{\circ} \mathrm{C}\right)$ と同じ時間帯にお ける一時間当たりの熱中症罹患による救急搬送者数 Np との比較である. 図中の 1 点が各月の一つの地上風向 変動パターンを示している. 


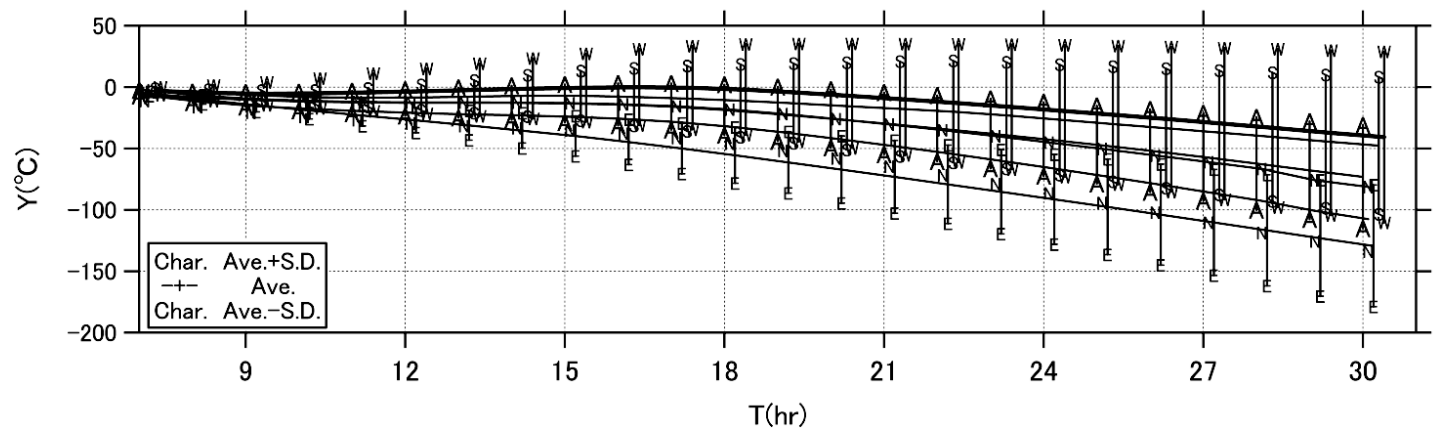

(a)6月

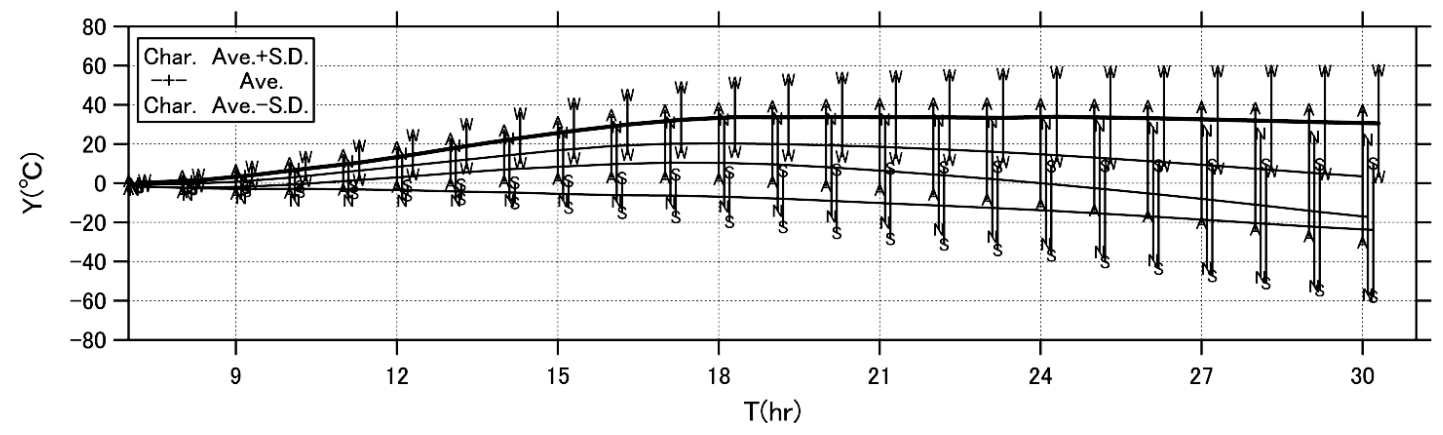

(b)7 月

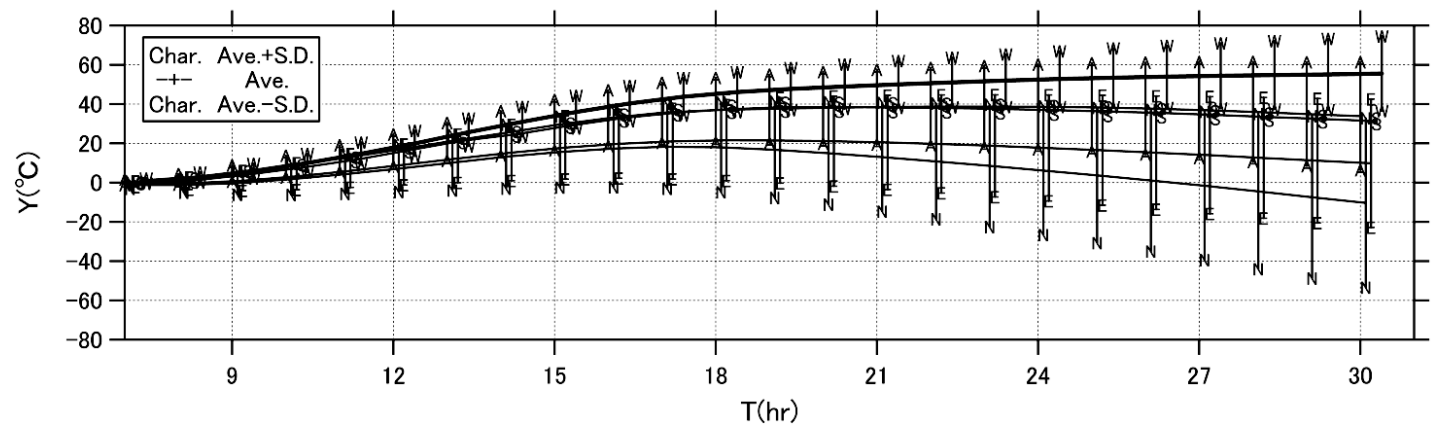

(c)8 月

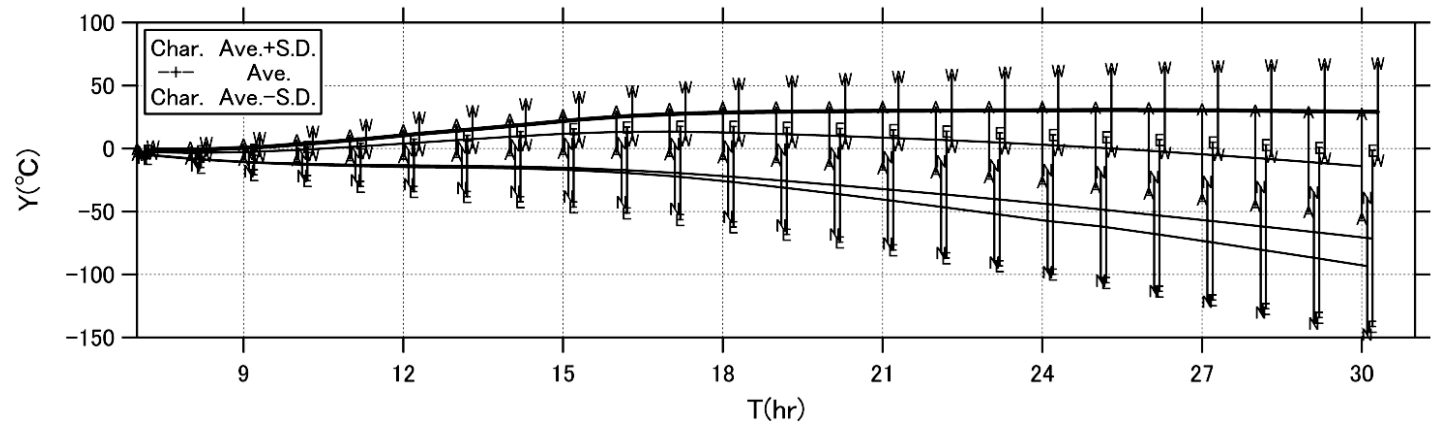

(d)9月

図-5 $\mathrm{Y}(\mathrm{T})$ の時間変化 
表-2 夜間における $\mathrm{Y}(\mathrm{T})$ の平均值の差の有意性

\begin{tabular}{|c|c|c|c|c|}
\hline & A & $\mathrm{N}$ & $\mathrm{E}$ & $\mathrm{S}$ \\
\hline $\mathrm{N}$ & $\begin{array}{l}\uparrow \bigcirc(※ 1) \\
\uparrow \times \\
\uparrow \bigcirc \\
\uparrow \bigcirc\end{array}$ & & & \\
\hline $\mathrm{E}$ & $\begin{array}{l}\uparrow \bigcirc \\
- \\
\uparrow \bigcirc(※ 2) \\
\uparrow \bigcirc\end{array}$ & $\begin{array}{l}\uparrow \bigcirc(※ 3) \\
- \\
\leftarrow \times \\
\leftarrow \times\end{array}$ & & \\
\hline $\mathrm{S}$ & $\begin{array}{l}\leftarrow \times \\
\uparrow \bigcirc(※ 4) \\
- \\
-\end{array}$ & $\begin{array}{l}\leftarrow 0 \\
\uparrow \times \\
- \\
- \\
\end{array}$ & $\begin{array}{l}\leftarrow \times \\
- \\
- \\
-\end{array}$ & \\
\hline W & $\begin{array}{l}\leftarrow \bigcirc \\
\leftarrow 0 \\
\leftarrow 0(\circledast 5) \\
\leftarrow 0(\circledast 6)\end{array}$ & $\begin{array}{l}\leftarrow(0) \\
\leftarrow(0) \\
\leftarrow(0) \\
\leftarrow(0)\end{array}$ & $\begin{array}{l}\leftarrow 0 \\
- \\
\leftarrow 0 \\
\leftarrow 0\end{array}$ & $\begin{array}{l}\leftarrow \times \\
\leftarrow \bigcirc \\
- \\
-\end{array}$ \\
\hline
\end{tabular}

各セル内第1 4 段 : 6 9月

$\uparrow:$ 列パターンが大きい， $:$ 行パターンが大きい, 一 : いずれか のパターンがない.

(○) : $1 \%$ 有意, $\bigcirc: 5 \%$ 有意, $\times$ 有意性なし

$※ 1: 21$ 時以前 $\times$, 以降○, $※ 2: 22$ 時以前 $\bigcirc$, 以降( $※ 3: 20$ 時以前○, 以降○, $※ 4: 22$ 時以前 $\bigcirc$, 以降 $\times$

$※ 5: 24$ 時以前 $\bigcirc$, 以降○, $※ 6: 23$ 時以前 $\times$, 以降○

同図より，月ごとに風向変動パターンによってまとめ ると, 夜間の $\mathrm{Y}(\mathrm{T})$ の平均値と 1 時間当たりの搬送者数 との間には強い相関関係があることがわかる，図中の害 線は，全てのデータを考慮した回帰直線であり，次式の ように表わされる。

$$
\mathrm{Np}=0.0015 \overline{\mathrm{Y}}+0.0910\left(\mathrm{R}^{2}=0.77\right)
$$

$\overline{\mathrm{Y}}=0$ の夜間の 1 時間当たりの救急搬送者数は 0.091 人 hrである．例えば，WBGT が 1 日中 $1^{\circ} \mathrm{C}$ 増加すれば， 12 時間後の $18 \mathrm{hr}$ には $\mathrm{Y}(\mathrm{T})$ は $12^{\circ} \mathrm{C}$ 増加し, 24 時間後に $24^{\circ} \mathrm{C}$ 増加することになるので, $\bar{Y}$ はこの時間内で平均的に $18^{\circ} \mathrm{C}$ 増加し, 1 時間当たりの搬送者数は 0.027 人 $/ \mathrm{hr}$ 増加 することになる. また, $\overline{\mathrm{Y}}=-20 \sim 0$ 付近で, 搬送者数 が 0.03 から 0.09 あたりへ急増しており，このあたりに 罹患者の増加の閾值があると考えることもできる.

図中 8 月のパターン W の W8 が突出して危険度が高 $<, 1$ 時間当たり 0.23 人/hr，18hr より翌朝 $5 \mathrm{hr}$ までの 12 時間を考えると, 平均的に 2.7 人の搬送者が発生する計

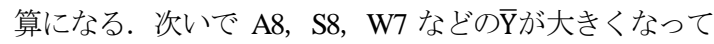
いる．それらのなかでも 7 月のパターン $\mathrm{W}$ の搬送者数 が多いことがわかる. 7 月のパターン間の比較において も，W7 が非常に大きくなっている， 6 月のパターン W についても，同月の他のパターンと比較して，搬送者数 が極めて多くなっており，相対的にパターン W が危険 度の高いパターンであることがわかる.この 6〜8 月の $\mathrm{W}$ は, 図中の回帰直線より上方にプロットされており,

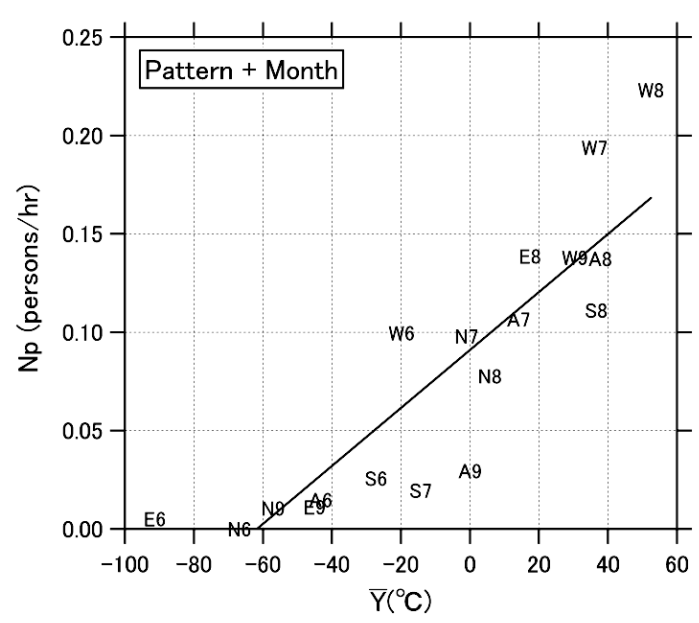

図-6 $\bar{Y}$ と夜間の 1 時間当たりの熱中症罹患による救急 搬送者数 $\mathrm{Np}$ との関係

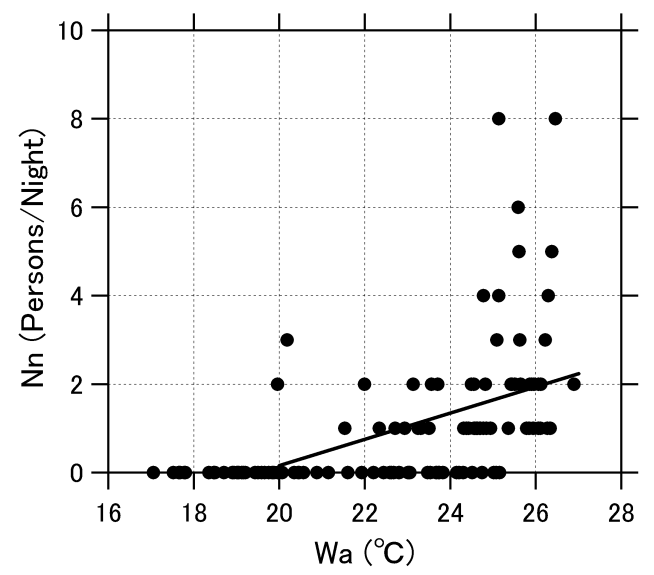

図-7 Wa と救急搬送者数 Nn との関係

この直線から予想されるより危険度は高いと考えられる。 また，9月のパターン $\mathrm{W}$ は, 同月の他のパターンより $\overline{\mathrm{Y}}$ が突出して大きことがわかる.

比較のために，図-7 に 2012年 6 9 月の各日の夜間の WBGT の平均值 Wa と熱中症による救急搬送者数 Nn と の関係を示している. 図中の実線は次式で示寸回帰直線 である。

$$
\mathrm{Nn}=0.297 \mathrm{Wa}+5.767\left(\mathrm{R}^{2}=0.28\right)
$$

有意水準 $1 \%$ で有意な中程度の相関関係が得られ，Wa が増加することにより Nn が増加することは確認される。 しかしながら，夜間の WBGT の平均值に対する熱中症 による救急搬送者数の変動は大きく，相関係数も相対的 に低いことがわかる。

以上の結果より, 地上風向変動パターンが熱中症危険 度の一つの指標となり得ることが確認できる。 


\section{4. 結論}

本論では, WBGT の低下した夜間においても熱中症 罹患者が発生することや，日最低気温が夜間の地上風向 に強く影響されるとのこれまでの筆者らの検討結果を念 頭において，地上風向の日変動パターンが熱中症危険度 の指標になり得るかどうかを検討した，主要な結果を以 下に示寸.

地上風向の日変動パターンによって WBGT の変動傾 向に差異があることを確認した. WBGT $\geqq 25^{\circ} \mathrm{C}$ を基準と した場合，18hr 以降の夜間において熱中症危険度が高く なるのは，7，9月のパターン $\mathrm{W} ， 8$ 月の全てのパターン であることがわかった。

WBGT 值を時間積分して暑熱環境の履歴を考慮でき る新しい指標を提案した．地上風向変動パターン別にこ の指標の夜間平均値を計算し, 昼夜を通して海からの風 が連吹するパターン W の平均值が，他のパターンに比 較して有意に大きいことを示した．月別パターン別の夜 間の平均值と熱中症罹患者数との間には強い相関関係が 認められ，パターンから夜間熱中症罹患による搬送者数 の予測が可能であることが示された．6から 8 月のパタ ーン W については，予測值を上回る搬送者数が発生し ており，熱中症危険度が高いことがわかった。

これらのことから，地上風向の日変動パターンが夜間 の熱中症危険度を表示寸る一つの指標となり得ることが わかった。

謝辞

大阪市消防局より熱中症罪患者数のデータの提供を受 けた，関係各位に謝意を表する。

\section{参考文献}

1) 中井誠一：熱中症対策の歴史，日本生気象学会誌雑誌，48(1), pp..9-14, 2011.

2) 日本生気象学会，「日常生活における熱中症予防指針」Ver.3 確定版, 2013.

3) 田村憲治，小野雅司，安藤満，村上正孝 : 救急搬送デー夕に よる熱中症の発生と気温，日本生気象学会誌，Vol.32, pp.111114, 1995.

4) 日本体育協会 : スポーツ活動中の熱中症予防ガイドブック， Part3，熱中症予防のための運動指針，pp.16-22，2013.

5) 南利幸 : 地球の温暖化と熱中症の予報について，日本 生気象学会誌，Vol.41(1)，pp.41-44， 2004.

6)玉井昌宏，川原大典，有光剛 : 大気環境リスク評価のための 気象シナリオ日の選定方法，環境工学研究論文集，Vol.47, pp.515-525, 2010.

7) 玉井昌宏，日比俊輔：大気環境リスク評価のための気象シ ナリオ日の適用性とターグットシナリオとしての利用法, 土木学会論文集 G（環境），vol.67，No.7，III_761-III_772， 2011.

8) 玉井昌宏，有光剛 : 大阪湾沿岸域の夏季夜間気温と海陸風の 関係，環境システム研究論文集，Vol.36，pp.397-405，2008.

9) 環境省 : 平成 21 年度 WBGT 観測による熱中症予防情報の提 供業務報告書，3.2WBGT 推定方法の制度検証，2009.

10) 空気調和・衛生工学会編 : ヒートアイランド対策 都市平 熱化計画の考え方，進め方，第 2 章 ヒートアイランドの基礎 物理, pp.25-39.

11) 岡田孜，岡田益己，日下博幸 : 岡田・日下の黒球温度推定 式の広域適用とパラメータ調整，日本ヒートアイランド学会論 文集, Vol.8, pp.13-21,2013.

(2014.5. 23 受付)

\title{
Study on Heatstroke Risk Indexes Using Daily Fluctuation Patterns of Surface Wind Directions
}

\author{
Masahiro TAMAI and Kenji SAWAI \\ Dept. of Civil Engineering, Osaka University \\ Land Development Dept., Gihu Prefectural Government
}

\begin{abstract}
The WBGT index is commonly used to indicate heatstroke disease risk but the index does not always expect the risk in night time correctly. The puopose of the present study is to examine whether daily fluctuation patterns of surface wind directions can be a indicator which appropriately expresses the night time risk. It is shown that fluctuation characteristics of the WBGT vary by the daily fluctuation patterns. A new index $\mathrm{Y}(\mathrm{T})$ which is calculated by time integrations of the WBGT and can take past records of sultry environments into consideration is proposed and it is also shown that fluctuation characteristics of $\mathrm{Y}(\mathrm{T})$ differ by the patterns. It is indicated that night time averages of $\mathrm{Y}(\mathrm{T})$ for each pattern correlate closely with nocturnal heatstroke desease risks and the pattern $\mathrm{W}$ which means that west wind blows all day long has the highest risk for nocturnal heatstrokes. From the above results, we concluded the daily fluctuation patterns of surface wind directions can be utilized as a indicator to expect heatstroke disease risks in the night time.
\end{abstract}

